\title{
The Metaphysics and Theology of Music
}

\author{
Vasile Chira \\ Lucian Blaga University of Sibiu/ Faculty of Theology "Andrei Şaguna" \\ Personal e-mail:vasilechira@gmail.com
}

\begin{abstract}
This article aims to analyze music from a philosophical and theological perspective, using the principles of multi- and transdisciplinary methodology. After a brief introduction, which presents the main moments in the history of the musical phenomenon, a first chapter addresses the metaphysical dimension of music in classical composers.

The second chapter shows the position of philosophers towards music, starting with Pythagoras and ending with Schopenhauer.

The third chapter focuses on music theology in general, but also on the theology and metaphysics of music to the French philosopher of Romanian origin, Emil Cioran, who, after Augustin and Schopenhauer, wrote probably the deepest pages on the ontology of music. The last chapter refers to to the archetypal character of music.
\end{abstract}

Keywords: Music, Metaphysics, Theology, Philosophy, classical music, religious music, mystic extasis, Archetype.

Motto:

"I cannot make a difference between tears and music. (Nietzsche)

"Were there not religion and music, I would become a bawdy house guard" (Emil Cioran)

"Mozart makes me regret Adam's fault" (Emil Cioran)

"I am as much as I sing. In the world, man, being alive, sings even his solitude.

Only dead he does not sing, but, even then, he sits and listens" (Romanian Folklore)

\section{Introduction}

Music (lat. musica; gr. mousiké = the art of poetry and song) is an infra-verbal sonic flow, of unknown origin, organized according to rigorous composing norms, having psychosomatic, cognitive and spiritual impact on the listener.

In the history of the spirit, music was defined in various ways, such as soul language, heart vibration, answer to a question that wasn't asked, art with immaterial matter, divine art etc., although we do not know the origin and nature of this sonic element. An honest answer to the question "What is music?" should probably repeat the answer given by the great Augustin of Hippo to the question "What is time?"

The most immaterial, the most pneumatic, the most touching, music is a sonic miracle, Gelasius' cry that probably belongs to the ultimate mystery of the universe. Being created by Divinity, man and music interlock, they generate one another in that we don't know if man is music or music is man, as much as God is music or music is God's breath. 
Listening to Bach's, Mozart's, Beethoven's music, we almost repeat the oneiric experience of that Asian who sometime, at night, dreamt himself being a butterfly and in the morning couldn't tell if he were a butterfly in his dream or he is a butterfly now, dreaming that he is a man. Well, music makes us wonder if we are human beings singing or divine pieces of music that materialized into bodies.

„At the beginning was the sound", we could say, by paraphrasing the well-known quote from John's prologue, because any existence, be it mineral, Earth ${ }^{1}$ essence or human, it spins, dances, leaves a sonic wave, speaks, weeps. The sound precedes the word ${ }^{2}$ which is formed of sonic units. God Himself, when He decided to create the world, the way religious cosmologies state, He used sound, lest His existence, His Being, His infinity, His silence were not the sound itself. The first composer to create this fugue we call cosmos was God. Similarly He, the supreme counter-pointer, switched history, changed the score of existence from "dying key" in an infinite ontological key. This thing is not only sustained by theologians but also by composers such as the great Bach who was the organist of a church and who used to begin his musical creations with a plead to God or to Jesus Christ by writing on each manuscript: Soli Deo gloria (Glory to The One God!) or Jesu juva me (Jesus, help $m e !)$.

At the beginning everything was singing, everything sounded: the rivers, the sea, the birds, the forests, the animals, the wind, the thunder. In order to get to know something, a phenomenon, a being, the prehistoric man had to listen.

Everything vibrates in the universe starting with plant blades shaken by wind blows to the planets that spin in the sidereal space.

Making reference to one of Goethe's metaphors, we could say that even the cosmos, the mountains, the antique temples, the grand mosques, the medieval cathedrals, the wooden churches in Maramureș and the monasteries in Northern Moldavia are nothing but "stone-still musical pieces".

Similarly, man is an instrument with stretched strings trembling when being touched by suffering or joy.

Speaking of the three cosmic spaces: the sea, the land and the air, Mahatma Gandi was trying to identify one essential quality of the beings living in these habitats; fish in the sea remain silent, the animals on land cry and the birds, fluttering their wings across the sky, sing. Man, in exchange, solely has these three qualities, bearing in himself the depth and silence of the sea, the cry of the earth and the height and song of birds.

Paradoxically, man is a musical instrument that creates music (two vocal cords, two flesh blades that vibrate when touching the air) or who is being played by, the way Blaisse Pascal plastically used to say: "When you touch a man you have the impression you touch a pipe organ. Men are real pipe organs. One must know where its keys are".

Unfortunately, few are those patient to play the instrument 'man'!

Man was not pleased to sing only by voice but made himself, along history, various instruments out of bone, lithopone, wood, leather or metal. In this manner we have an evolution from the cattle horn to the flute, from turtle shells to string conches, to violin and

\footnotetext{
${ }^{1}$ About the music of spheres at Pythagora see in Chira, Vasile (2007), Istoria filosofiei presocratice în 492 de capete(The history of presocratic philosophy in 492 chapters), "Lucian Blaga" Public University Press, Sibiu, p.43-50.

${ }^{2}$ Speech is approximately 80000 years old while singing appeared 500000 years ago, and instrumental music 40000 years ago.
} 
viola, from the mammoth bone flute to the pipe organ. Out of his yearn to express infinity by sound, man invented musical scales, notation systems, games and modes.

Starting with the sound of reed blades in the blow of wind, from strikes between stones or wooden objects in the middle paleolithic, by which the primitive man manifested his gratitude to gods, to Bach's or Beethoven's technique, there is a long and ardous way.

After centuries of monody (an ode sung by a single actor in a Greek tragedy), we may have polyphony reaching a peak in XVI century by French-Flemish and Italian composers: Machaut, Ockeghem, Dufay, Lasso, Marenzio sau Palestrina.

During the pre-classical period (XVII century and the first decades of XVIII century) there is a transgression to the harmonic style and implicitly to the major-minor tone system. Composers like Monteverdi, Vivaldi, and Corelli combine singing with instrument playing, developing thus a new musical genre: the opera.

During the classical age - prepared by Bach and Handel - composers like Haydn, Mozart, and Beethoven will shape the structure of a sonata, a symphony and of a quartet.

The Romantics Schubert, Weber, Schumann, Chopin, Berlioz, Liszt or Wagner free lyrism and Dionisiac impulses. Schönberg establishes dodecaphonism. Neoclassicism, represented by Ravel, Stravisnki etc., tried to maintain a connection between contemporaneity and musical tradition. Enescu, Bartok, Janacek and Szymanovschi insert folklore(Bălan, 1965, p.7-10) themes in their compositions.

\section{The metaphysical dimension of music}

Music was especially defined as the art of feelings and emotions, although, if we pass beyond this sonic combination, which makes us contemplate and fall into extasis, making use of our intellect and cognition, we will sense a more profound level of this art, namely music's capacity to generate reflexive moods, to really produce ideas.

We must mention the fact that even skillful speculating and genius philosophers like Kant or Hegel missed the cognitive, philosophical dimension of music as they would consider that, speaking only by "pure sensations", music is exclusively of the soul, of the feeling, being uncapable of intellectual ${ }^{3}$ content.

Indeed, the composer cannot directly operate with the instruments of logics, ontology or gnoseology, but musical language allows suggesting some themes belonging to these philosophical areas. Similarly, music may inspire the attachment to eternal human values: the good, the truth, the beauty (Bălan, 1973, p.13).

It is hard to accept the fact that great composers like Beethoven, Chopin, Brahms, Ceaikovski or Mahler created their symphonies, sonatas and quartets for the sake of sonic arabesques that should enchant only the hearing, without being animated and have in mind a noble and profound(Bălan, 1973, p.20) . ideatic dimension.

Music is not only esthetic emotion, sweet sob-stuff, easy entertaining, acoustic euphoria, rithmical hedonism, the way one of Caragiale's characters would consider, and who used to say that "music is something that tickles the ear in a pleasant way". Great music is invitation to reflection, it is sonic revelation of a being's ultimate feelings, it is metaphysical interrogation, it is a thinking manner that replaces concept with sound, it is metamorphosis, and it is epiphany.

\footnotetext{
${ }^{3}$ Immanuel Kant compares the evanescence of musical hedonism with the effect of a perfumed handkerchief. Its smell is strong and catching but disappears quickly.
} 
Not coincidentally, Bach's music was associated with Leibniz's monadology, with Kant's philosophy or with Spinoza's ethics (Bălan, 1973, p.52).

The composer is a poet and philosopher at the same time, he does not manifest ambitions to compete with Kant or Hegel, and yet, however, by his quill pen he creates truthful revelations on man and nature, life and death, existence and fate (Bălan, 1973, p.56).

This is, moreover, the reason why Schopenhauer changed Leibniz's definition on music from: „muzica est exercitium aritmeticae occultum nescientis se numerare animi"4 into „musica est exercitium metaphisicae occultum nescientis se philosophare animi”.5.

Many times, the great philosophers' ideas influenced classical music. Wagner, for example, reads Schopenhauer's work "The World as Will and Representation" a year before writing "Tristan and Iseult". Overflowing pessimism in this work, like the ascetics of vision in Parsifal, owe a lot to Schopenhauer's philosophy. Similarly, Nietzsche's thinking influenced Mahler's III-rd Symphony and Richard Strauss's symphonic poem "Thus Spake Zarathustra".

Next to works with deeply reflexive content, like the ones belonging to Bach, Beethoven, Mozart, Wagner, Mahler, Debussy, Enescu or Bartok, there are more accessible, more terrestrial works that are meant to make men's lives more agreeable. Honorable composers like Grieg, Rahmaninov, Gounod or Puccini(Bălan, 1973, p. 87) . (even if they did not reach the height of Bach or Beethoven) are part of this category.

The Composer, being by nature a hyper-sensitive being, is almost predestined to confound himself with man's great interrogations: the reason of life, freedom, and theodicy, the infinit, suffering, illness and death.

Bach's St Matthew Passions, Beethoven's III-rd Symphony, Brahms' IV-th Symphony, Mahler's IX-th Symphony, Enescu's Oedipus or Sostakovici's X-th Symphony express with shades and different dosages the tragic of existence.

On the other side, brightness, the joy of life that someone like Vivaldi, Couperin, Ravel, Poulenc or even the great Mozart transmit, may be the outgrowth of some soul dramas they managed to overcome. Such an attitude becomes natural if we have in mind the fact that lucidity and inner dramatism influence one another mutually(Bălan, 1973, p.98) .

Nevertheless, the composer, thanks to some acknowledged composing procedures and techniques, does not express in his musical discourse only the geography of his own self, but also the self of the world, the pulse of the universe and of society.

Romanticism determines the esthetic discourse to identify in symphonic music, next to the emotional dimension, the spiritual message as well, this one transceding the aural flow. This revival of reflexivity, of loading music with transcendental connotations, comes as a continuity of bimillenary tradition: Pythagora and Platon considered music the echo of spheres; Augustin saw in music a means to contemplate divine infinity; for Hegel, music represented a stage in the story of the Spirit's self-affirmation in the world; Schelling identified music with the cosmic rhythm.

Saloon music, the attitude towards it as being an entertainment generator, on the background of which there may be conversation and joke telling, would have been criticized by Ernest Theodore Amadeus Hoffmann (1776-1882), a writer, a composer and music critic contemporary to Beethoven. According to him, music, this "sacred art", is not just fun

\footnotetext{
4 "Music is an occult arithmetic exercise, in which the spirit does not know it counts".

5 "Music is an occult metaphysical exercise, in which the spirit does not know it makes phylosophy".
} 
occasion for "the ears of a brute" but it reveals man a world, different to the world of natural phenomena(Bălan, 1973, p.113-114) .

Nevertheless, the one who would make theory and impose in esthetics and philosophy the gnoseologic function of music is Arthur Schopenhauer who in "The World as Will and Representation" states that music makes a connection between man and "the thing in itself".

Next to their composing work, many composers write about music critically, often shaping their own esthetic programs. We refer here to Beethoven's letter writing and conversation notebooks, Weber's, Schumann's and Berlioz's articles, Liszt's musical studies, Wagner's theoretical work (The Opera and the Drama, The Future Work of Art etc.), Bartok's folkloric studies or Enescu's memories.

Musicians sensed and expressed the tragic of human condition even before pessimistic phylosophers did. Thus, we speak about existentialism or existential thinking not only in philosophy and literature (Schopenhauer, Kierkegaard, Nietzsche, Heidegger, Sartre, Camus, Gabriel Marcel, Cioran) but also in music, even if in this art the cry of suffering, the anguish are joined by the idea of battle.

Partially in the case of classicists, but especially in the case of Beethoven, angelic hymns, the seraphic of former composers will be replaced by battle cries, with prometheic accents.

Even Mozart, despite his angelic soul, during the last period of his creation will voice some deep melancholy(Bălan, 1973, p.170-172) .

\section{Philosophies and music}

\subsection{Music at Pythagoras of Samos}

To the philosopher of Samos, the essence of reality is reduced to arithmetic relations, the number being in fact that principle of things (arhe) that presocratic philosophers had generally been looking for.

Everything vibrates in the universe starting with reasonable and dumb animals' vocal chords up to the cosmos to the planets. It is well known Pythagoras' theory that the spheres in their rotation produce an extraordinarily beautiful music that we do not hear because we have become accustomed to it since the birth of the music that the spheres.

Vibration means the sound whose height on the musical scale is given by the lesser or greater number of vibrations. However, Pythagoras had this genius intuition while strolling his fingers on an instrument with a single string (monochord). In the case of two strings vibrating, one being twice as long as the other, the shorter string will render a higher sound. The highest sound produced by the short string will be in an octave in relation to the lowest sound produced by the double string(Chira, 2012, p.20).

If the string length is in a ratio of $3 / 2$ we will have the quint, while in a ratio of $4 / 3$ it will render the quart. Once these intervals discovered, there was also discovered the Greek diatonic scale whose notes were named 'ut' (the XVII century do), re, mi, fa, sol, la, si by the Benedict monk Guido d'Arezzo (997-1050), according to the name of the first syllabus of a religious hymn, which culminated at the end of the Medieval Age with the introduction of the major scale with just intonation. In conclusion, music has deep relations with mathematics, especially when we speak of harmonic procedures (sound suppression in accords, accords of dominant seventh chord, descending alterations, modulations etc.). 


\subsection{Music and Classical German Phylosophers}

Classifying arts, Immanuel Kant considers that the higher and the clearer the ideatic substance of an art is, the more superior it is. Therefore, the art of music may be classified the last, next to the art of colour combination, after rhetoric, architecture, sculpture and gardening, arts in which the ideatic element is outshined by sensorial reality.

For Kant, music used to be an art that lacked urbanism, a game of sonic arabesques in which we have "more entertainement than culture".

By excluding the cognitive function, the pedagogical role and the spiritual content of music, Kant establishes the formalist theory about music.

Contrary to Kant, Fichte places an accent on the role of the listener in decoding accustic meaning. He, the listener, unites diversity and unity, his inner self builds harmony and consonance. Fichte's attitude towards music is, certainly, in agreement with his own philosophical thinking: subjective idealism.

According to Schelling, music renders, with an ability superior to the other arts, phenomenal growth. It expresses the pure form of this dynamism, surely having a connection with cosmic structures. The rhythm, for example, expresses periodicity of moving planets. In the dialectics between rhythm, melody line and harmony, the ruling and unifying function is assured by rhythm having the same role in music and in cosmic dynamism as its philosophical concept of objective idea, the only one that can solve conflicts between self and non-self, uniting them in a transcendental identity(Bălan, 1966, p. 65-67).

For Hegel, music, next to painting represents an important step in the struggle of the spirit to detach from matter, even if music expresses the spirit in a manner insufficiently determined.

Hearing is, according to Hegel, "ideal" in comparison to sight, statement that comes to strengthen that music pervades the soul.

On the other hand, Hegel does not accept that music may express ideas unless it is doubled by word, by poetry. Otherwise, it only expresses "emotions without reason".

Although he has moments when he oscillates between the "abstract subjectivity" and "spiritual content" of music, when he speaks of religious music (catholic and protestant), Hegel is of opinion that it embodies divine essence.

In conclusion, we may say that Hegel's esthetics, in comparison to Kant's, records a great progress, in that the author of "The Phenomenology of Spirit" grants music with the possibility to express spiritual content(Bălan, 1966, p. 70, passim).

\subsection{Schopenhauer and Music}

Schopenhauer classifies arts according to the manner in which they manage to evoke the spiritual dimension of life. If at the bottom of this pyramid we may find architecture, an art operating with a huge volume of matter, poetry reigns at its top.

In comparison to the other arts, for Schopenhauer music has a special status, it being not the copy of ideas but the copy of will itself: "All the other arts make the will objective only indirectly, namely through ideas; and while our world is nothing but manifesting ideas in multiplicity by adapting a principium individuationis (the shape of possible knowledge for an individual, in himself), music - because it ignores ideas, being totally independent of the phenomenal world - could exist even if the world didn't exist, a thing that is not to be said about the other arts. In conclusion, music is direct objectifying and a copy of entire will, the way the world itself is, and even the way ideas are, whose multiplied manifestation 
constitutes the world of particular objects. Therefore, music is not the copy of ideas, the way it happens with the other arts, but a copy of will itself, whose objectivity are ideas as well; that is why the effect of music is much stronger and overwhelming than in the case of other arts, for the latter speak only about shadows, while music speaks about essence"(Schopenhauer, 2012, p.299-300).

Music is accustic mathematics speaking of numerical ratios without concepts. The relation between the metaphysical dimension of music and these numerical ratios may be deducted from the fact that "the irrational element or discordance naturally represents what is contrary to our will; and viceversa, consonance or the rational element, because it easily adapts to our will, becomes the illustration of will satisfaction. To continue, as the rational or irrational element in the numerical ratios of vibrations admits numberless stages, tints, successions and variations, music becomes, due to them, the matter in which all the impulses of human soul, namely of the will - a means whose essence is always reduced to getting satisfaction, although in various degrees -, may be reproduced and rendered accurately in the finest shades and alterations, a moment which comes up once the tune is created. Here we may see how the means of will are transposed to the field of pure representation, which is the only scene where creations belonging to all fine arts manifest themselves"( Schopenhauer, 2012, p.478).

Due to the speed with which vibrations succeed, high sound finds greater interest in the listener than lower sounds, soppranos representing thus the boosted status of conscience. Opposite to this we may have "the heavy bass, that ascends and descends only at high intervals, -thirds, quarts and quints-, each led at every stage by fix rules; it is, thus, the natural representative of anorganic natural life, insensitive, non-perceiving fine impressions and it can only be determined by general laws." "(Schopenhauer, 2012, p.479)

The essence of a tune is given by a succession of "discords" and "concessions" between the rhythmical element and the harmonic one. Without such an opposition and concession, the melody may not reach its purpose. Behind these fine musical alternations we may discover the treacherous change of will: "Metaphysically, "discordance" and "concession" that happen continuously between the two elements embody the emergence of new desires, and subsequently their satisfaction. Precisely through this, music pervades into soul, deceiving it and pretending to permanently satisfy all its wishes" "(Schopenhauer, 2012, p.483).

The same as life, musical harmony consists of the variation in discordances and consonances that obviously function according to accurate rules. In fact, music could be reduced to only two basic accords: accords of dominant seventh chord and harmonic accord of three notes that have a subtle correspondence with our emotional state of mind: "for human will, there is not, in fact, anything else but satisfaction and insatisfaction, no matter the number of forms these may embody. The same way there are, generally, two fundamental states of mind: serenity or - at least - joy or sadness or - at least - mental pressure, similarly music has two general tones: major and minor, correspondent to the mentioned states of mind, and in conclusion it should always alternate between the two. In fact, however, it is extremely amazing that the minor tonality is a sign of pain which, not being psychological or even conventional, it still attracts us, representing pain unmisteakably. According to it, we may estimate the deep roots of music in the nature of things and human beings. Speaking about Northern peoples, whose life is subject to difficult living conditions, namely the 
Russian people, the minor tonality is a dominant, even in Church music" "(Schopenhauer, 2012, p.484).

\section{The Theology of Music}

For John Chrysostom music is the imitation of angelic song, the singer/player being inspired by God. We sense here the influence of Plato's theory of ideas according to which arts are but faint copies of paradigms, although, paradoxically, Chrysostom did not agree to Plato's philosophy.

Blessed Augustine, in „De musica”, speaks of a scale of beauty that, being climbed by man, may lead to God's contemplation. While at the bottom of the scale we may have sensorial satisfaction, physical beauty etc., and at the top of the scale, spiritual beauty that one may reach by practicing Christian virtues, art is situated somewhere at the middle of the scale.

Henceforth, music is, for the author of "The City of God", one of the means by which man may come close to Divinity, given the condition that this art may respect certain numerical ratios.

As we may observe, Augustine emphasizes more Pythagora's arithmetical, cerebral structure of music than its artistic, ideatic, phylosophical dimension.

Later, Boethius is tempted to exclude music from the range of arts, considering it just pure theory. For him, music is reason and speculation and real musicians are not the ones practising music, the so-called "cantores", but the ones that theoretically acquire musical science with the help of arithmetic and logics. The latter are called by the author of $D e$ consolatione philosophiae „musicii”.

In scholastic Middle Ages, the Catholic Church interdicted by edicts "lay music", that "defile the ears of listeners". Only certain modes and intervals were admitted, few in number, which the Catholic clergy had considered compatible with religious spirit. For example, the increased quart was named ,Diabolus in musica”.

With Thomas d'Aquino, the greatest Christian brain, the role of music in relation to Christian doctrine is reconsidered in such a manner that music obtains the status of an art next to that of science.

In his study „De arte musicae” music is the first of the seven liberal arts. Musical art is meant to bring man closer to God, to comfort man in the sadness of life and cheer the limp and the timorous.

Thomas's esthetics will start emancipation in musical discourse as compared to Gregorian melodies and would make it evolve towards the art of polyphony(Bălan, 1966, p. 30-34.

For ancient fathers, music is the language of soul. Its influence over human being is a lot greater than that of word.

It is known that Seraphim Rose embraced Christianity due to a cantata ${ }^{6}$ by Bach, Ich Habe Genug (I Have Had Enough), that speaks of death and the soul odyssee after it separates from the body. In this cantata, written in fact for the feast of the Theotokos purification (The Entry of the Most Holy Theotokos into the Temple - a feast in Orthodox Tradition) there are three arias interpreted by baritones, and which genially surprise a being's yearn for celestial homeland. The lyrics are of heartbreaking delicacy: "I have had enough! I have received the Saviour, the hope of the faithful, in my yearning arms. I have had enough! I have seen Him; my faith embraced Jesus, and today I would gladly pass away. My only

${ }^{6}$ We speak here of cantata no. 82 . 
hope is that Jesus be mine, and I should be His. I join Him faithfully and, like Symeon, foreseeth I the joy of life in heaven. Let us join Him! Oh, had the Lord loosed the chains of my human shape; and had the time of my leaving come, gladly would I tell the world: «I have had enough.»

Sleep yee, unrested eyes, close yee, gently and, at peace. World, I will not linger any more in thee. I leave thee, for I want my soul to be able to rise. Here all is pain and there, I will see sweet peace, absolute rest. My God! When You call me next to Thee, I shall lie deep in the cold grave and find my rest in Thee. I say Good bye. Good night to Thee, world!"

\subsection{Emil Cioran on the theology and metaphysics of music}

The crossing of Cioran's nihilism with music cannot be understood outside Eden's nostalgy. Cioran's concern for music is not a cultural or esthetic one, and it is not "existential" either. It rather relates to the memory of a lost Transcendence that most mistics claim, even if it doesn't interpret this anamnesis in the sense of pre-existence in the world of the spirit or, contrary to this, in the sense of a memory of species that preserves the meaning of paradise in each individual that came into being. Music becomes a kind of impious mystic, a means of access to Transcendence for those who cannot bring to an end the burdens of ascetics.

Having a doubtful structure, condemned to inconsistency, to an attitude that is perpetually to be found under the sign of skepticism, Cioran is liable, simultaneously, to experience extasis as well as to deny it furiously. Cioran's conflicts, projected to a metaphysical scale, become, in fact, the Divinity's contradictions. Music is the only means that may conciliate skepticism with holiness and henceforth, the incompatible positions man has in front of the Absolute( Chira, 2006, p.78-79).

If Cioran had an ambiguous attitude towards holiness that oscillated between eulogy and disparagement, in front of music, Cioran's denying propensity would undergo a strange palsy. The one that can blaspheme God, the cosmos, life, man and woman alike, cannot blaspheme music. Music becomes the limit of Cioran's nihilism: "When the entire existence becomes music and your whole being a vibration, that's where remorse stops" (Cioran, 1996, p. 61).

As "the language of trancendence", music is the one offering the skeptic the feeling of immortality: "Only musical hapiness gives me the feeling of immortality. Those serene days when the heart takes the colour of the sky and in which accustic extases with memories beyond the horizon take place! In vain would one look for tears because of time" (Cioran , 1996, p. 34).

Music belongs to the same trancendence of human condition that any religious experience takes into account: "To the world of music one may get only by overcoming human condition. Music is an infinite universe, including its subtle and fading character. And individual, who, insensitive to its magic, cannot pervade into it, lacks the reason to exist itself" (Cioran , 1996, p. 35).

The Absolute to which we do not have access but intermittently, becomes the fundamental source of regret. The inability to make the extatic experience of Divinity permanent may be transformed into remorse, atrocious suffering and even blasphemy. In this respect, Cioran may be considered a denier born out of a rejected mystic, he may be considered a heaven's resented. "It is, indeed, the Absolute seen in time, but he is incapable to remain in it, a contact at the same time supreme and transient. In order to remain in it, there is a need of a permanent musical feeling. The same happens with mystic extasis fragility. In both cases, one may experience the same feeling of unfulfillment, joined by heartbreaking remorse, by an endless nostalgy" (Cioran , 1996, p. 36). 
Another cause of Cioran's nostalgy is given by an acute memory of paradise that music fundamentally updates: "Mozart makes me regret Adam's fault" (Cioran , 1996, p. 37).

Essentially, Cioran's attitude in front of music is Cioran's attitude in front of Eden. Accusing paradise of eleatism that can bore the spirit, Cioran admits in the temporal shape of Eden, which is music, that Transcendence experiences melancholy. Named by Cioran "conceptual alcohol", "metaphyisical drunkenness", music seems to be related to another nature of Eden than the one of eternal uniformity. Although, between angelic boredom, seen by Cioran in relation to paradise, and "metaphysical drunkenness" there seems to be a contradiction, both images of Eden are connected to Cioran's position towards original sin. The paradise becomes, on the one hand, the farthest you are thrown away from it, the more visible. The paradox of a purposeful denier is that of placing himself close to the paradisiac principle that infinitely amplifies his nostalgy and, at the same time, having the access to the constant and extatic joy of Divinity obstructed( Chira, 2006, p.80).

Music is, for Cioran, a form of metaphysical illusion. Musical extasis stops as soon as music stops. What is different in the description of a mystic regarding his extatic experiences and the description of Cioran regarding his musical extasis is consistency. Any saint that had a revelation describes God as reality in excellence, the absolute consistency. In the war Cioran fights with Divinity, music remains the only direct thread he has with his own opponent, which determines him to conclude a metaphysical truce from time to time. Music remains the only temporal means by which God's beauty is directly communicated. Therefore, for Cioran, music is another alternative to praying, a means by which a denier may thirst for God( Chira, 2006, p.80).

Music, being of divine essence, its accords work as paradisiac "anamnesis": "the fact that music is of no human essence, what would more prove than the fact that it never araised in me the Inferno representation? Not even funeral marches. The Inferno is present reality, which means that we can only remember Paradise. Had we known in our immemorial past the Inferno, would we not remember it with sweet sobbing, would our regrets not speak of a lost Inferno? Music is memory archaeology. Its excavations do not discover in any nook an Inferno that might precede memories" ( Cioran, 1995, p. 69).

Once the musical extasis is consumed, inadaptability to the misery of life arises because music, especially the solar one, increases the contrast between cosmic putrefaction and the paradisiac space: "For music destroys the interest for action, for the immediate data of existence, for the biological fact in itself and maladjustes the individual. Music creates personal tensions that make one experience the feeling of continuing a useless life and this feeling expresses maladjustment. More than poetry, music weakens the willingness to live and life's vital resorts"(Cioran, 1991, p. 44).

Nevertheless, there is a difference, according to Cioran, between extra-musical sadness and the one determined by music, the latter being more diminished in force, in comparison to habitual depression: "In music the void is converted to plenitude, which might be nothing but a void that vibrates. All moods transform into musical feelings and are endowed with new caracteristics, because it deepens and makes all moods, up to vibration, subtle, consuming them into convergence and accustic immateriality... they experience a full transfiguration that makes personal sadness vibrate and lose its material character." (Cioran, 1991, p. 43). Music might replace the intelligible space Platon speaks about: "Why visit Plato if a saxophone can make us, similarly, discover another world?”(Cioran, 1992, p.114). 
In fact, Cioran does not listen to classical music out of esthetic reasons, but out of metaphysical, existential, therapeutic ones; it mediates between him and the abyss, its accords defending him of the unbearable silence of nothingness: «Music alone may become substance in the absolute void and all seas withdrew to make bed to tears»( Cioran, 1995, p. 207).

Thorough inadeherence to the world, the absolute bet of nothingness might, nevertheless be a vaccine against musical extasis, revealing the radical skeptic the illusions of sound art. Ontological decline confirms our relation with the demonic principle: "Borderline case of irrealism and absolute, real fiction, a lie more real than the world, music loses its spell once we, insensitive or somber, separate from Creation, Bach himself sounding like wishywashy noise to us; it is the extreme point of our unsympathising with things, of our coldness and decay. To grin on the heights of sublimity - that's the sardonic triumph of the subjective principle that relates us to the devil! Woe to him who has no tears for music any more..."(Cioran, 1998, p.161).

Among the musical experiences, the ones that are privileged due to the power of communicating the greatness of the Absolute, we may find those of Bach and Mozart. This music remains, for Cioran, an example of excellence, permanently contrasting with this lost world. Bach is the one who gave the most convincing expression of Transcendence in the immanent: "Without Bach, theology would lack object, creation would be fictional and nothingness - undeniable. If someone owed anything to Bach, that one would be God." (Cioran, 1996, p.112).

Making Bach an apologist of Divinity, Cioran seems to admit the fact that He remains the source of Bach's music too. This thing is contradictory to the gnostic metaphysical scenario that Cioran had so much affinity for. An evil demiurge cannot be the author of such excellency. Admitting the fact that one and the same divine reality created both a stranded cosmos and excellent music, Cioran emphasises the antinomic nature of Divinity. Bach's music is, in essence, a theodicy lesson and, at the same time, eschatology: "Bach is the direct agent of unearthedness. There is so much transcendence in a viola vibration, it looks like one sprinkles snow on the hearts of angels...In Bach we will not find "feelings", but the world and God tied by a pile of tears" (Cioran, 1996, p.111).

Bach's music is at the same time an ontological argument: "When you listen to Bach, you see how God becomes vivid. For his music generates divinity. A plastic vision of the divine being is unfolded to you and God becomes great as you look up.

After listening to an oratorio, a cantata or a "passion" by Bach, there must be another God. Otherwise, all of Bach's music would be a hearbreaking illusion, being too undefining to be turned into esthetic relish. We can't tell what used to be in old times. God has existed only since Bach...

... And when you think that so many theologians and philosophers have lost days and nights in searching arguments for His existence, forgetting the only valid argument: Bach" (Cioran, 1996, p.113).

Becoming ontological argument, it becomes at the same time the nihilism's unique means of surrender in front of Eternity: "In the Saint-Severin church, listening to the Art of fugue, pipe organon played, I could not stop repeating to myself: here is the invalidation of all my anathemas". (Cioran, 1996, p.112).

Mozart, in his turn, is the one that doubles Bach in his position of Transcendence defender. Mozart is that composer who is essential not in unhappiness but in serenity: "Man can 
only be essential in unhappiness. Will Mozart attract us only as exception? I wonder, did we learn the depth of serenity only from Mozart? Every time I listen to this music, I grow angel wings. Why did I not crash? The Mozart in me saved me" (Cioran, 1996, p.38).

Bach's music expresses not only the drama of human being and his/her yearning for the lost paradise, but also the tragedy of fallen angels: "Nostalgy is so essential to this music that you may ask yourself if Bach had known another memory than that of paradise. A huge and irresisting call vibrates in it, and what would be the meaning of this call if not that of taking us out of this world? With Bach we dramatically soar into the heights. He who, in the extasis of this music, had not felt his natural condition to be evanescent and had not lived the series of possible worlds that stand between us and the paradise, would not understand why its tonality is as much as the kisses of angels... Bach invites us to a crusade in order to discover in human soul, beyond the surface, the remembrance of a divine world. Did man understand this, thinking that he might caress it with such excitement? Did he not address his calls and caresses to a world of angels whom only the stellar temptation of sin had broken their wings and threw them from heaven here, where things come to life and die? All of Bach's music is an angelic tragedy. Terrestrial exile of angels is the reason and its hidden sense. That is why we may understand Bach only when we are far away from our humanity, when we live our first memory."(Cioran, 1991, p. 102-103).

If the music of Mozart is, according to Cioran, "the official music of Paradise" .(Cioran, 1991, p. 102-103).Bach makes the ascent to Eternity easy: "With Bach, we feel like standing at the gates of Paradise; never inside it" (Cioran, 1991, p. 102-103).

As compared to Mozart and Bach, Haendel and Haydn are terrestrial, pastoral, and Beethoven, through his heroism, lowers the music from the transcendental spheres to the immanent space: "Beethoven expelled God from music, because of the heroic element that would predominate. Until him, it expressed regret filled with heavenly perfume. Beethoven's heroic invasion made transcendence lay, similarly to a human drama. I am aware of no music more political than his. A triumph over the world, but not beyond it. Beyond the world? But Beethoven did not have, for a single moment, the nostalgy of Paradise..."(Cioran, 1995,p.148).

\section{Music and Archetype}

The music undoubtedly has an archetypal character. The same melodic lines in folklore are found on different continents without the respective populations having heard each other.

After he collects and harnesses folklore from Maramures area( Romania) the composer Bela Bartok reaches the conclusion taht some musical pieces have a structure and melodic line similar to folklore in Africa.

The long hora in Maramureș (,hora pa lungu”- Romanian dance - t.n.) has common parts with Persian, Iraqi, Tibetan or Chinese folklore. This ancient way of playing music, an archetype, a melotype, having the savour of dirge, in the measure of $6 / 8$ with "hiccupped grace notes" with glottis strikes and voice gliding on consonants (zîi, hîi), is an expression of a hyper-sensitive peasant in Maramureș. We deal here with cosmic lamentation which gives voice to Dacic people threnodies, the warriors' cries, children and widow weeping, the sound of bells accompanying the sorrow of death, courage, joy, but also the sadness of being. 


\section{Conclusions}

The musical phenomenon was not only adored but also criticised. Such impugnement appeared eversince the elenistic period. For example, according to Philodemus (I A.D.), an Epicurean philosopher, music cannot have a benefic influence on soul because it has no ideatic base expressed according to the rules of logics, being a succession of accustic feelings, irrational and that lack consistency.

The skeptic Sextus Empiricus (II A.D.) in "Against the Musicians" is even more radical. For him, music is a means of entertainment, without pedagogical or cosmic relevance, henceforth, useless.

Beyond the critique and praises brought to music, this remains an accustic expression of the inexpressible, of transcendence.

Due to this, the great conductor and composer Sergiu Celibidache refused to record the concerts he conducted, qualifying discs as "singing pancakes". Music is not a static, eleatist phenomenon, it becomes and it is born under the eyes of the interpreter, of the audience.

For the famous Romanian conductor, the accustic space is reduced to two dimensions. Henceforth, music cannot be captured, immortalized, because sound is not music in itself, but it may become music. Making sound perennial paradoxically represents its death.

Music belongs to transcendence, and transcendence cannot be captured, no matter how accurate the technical means.

Music truthfully accompanies human becoming from the lullaby song to the funeral march, it helps us return to our inner self, to accept our being but also to leave it when time comes. $^{7}$

\section{PhD University Lecturer VASILE CHIRA "Andrei Șaguna" Theological Faculty of Sibiu "Lucian Blaga" University of Sibiu/România}

\section{References}

Bălan, George .1965. Sensurile muzicii (The Meanings of Music).Bucharest: Tineretului Publishing House.

Bălan, George.1966. Muzica, temă de meditatie filosofică, (Music, A Theme of Phylosophical Thinking). Bucharest: Stiintifică PH.

Bălan, George.1973. Muzica şi lumea ideilor (Music and The World of Ideas. Bucharest: Uniunea Compozitorilor PH.

Chira, Vasile .2006. Dominantele gândirii cioraniene, (The Dominant of Cioran's Thinking). Sibiu: Universitatea „Lucian Blaga” PH.

\footnotetext{
${ }^{7}$ Donalyn Gross, an American specialist in palleative medicine, a musician by profession, composed an album with the title "Music for the Dying", meant to induce a state of serenity to those who would be dying.
} 
Chira,Vasile .2007. Istoria filosofiei presocratice în 492 de capete(The history of presocratic philosophy in 492 chapters). Sibiu:“Lucian Blaga” Public University Press.

Chira, Vasile.2012.Lecţii de filosofie (Philosophy lessons). Sibiu:"Lucian Blaga” Public University Press.

Schopenhauer, Arthur.2012. Lumea ca voinţă si reprezentare (The World as Will and Representation) vol. I, transl. by Radu Gabriel Parvu. Bucharest: Humanitas PH.

Cioran, Emil.1996.Cioran şi muzica .Antologie. (Cioran and Music. Antology), text selection by Aurel Cioran, Edition coordinated by Vlad Zografi.Bucharest: Humanitas PH.

Cioran, Emil.1995. Lacrimi si sfinţi (Tears and Saints), Humanitas PH, Bucharest/Romania. Cioran, Emil.1991.Cartea amăgirilor (The Book of Deceptions). Bucharest:Humanitas PH.

Cioran, Emil.1992). Silogismele amaraciunii, (Syllogisms on Bitterness). Bucharest: Humanitas PH. 